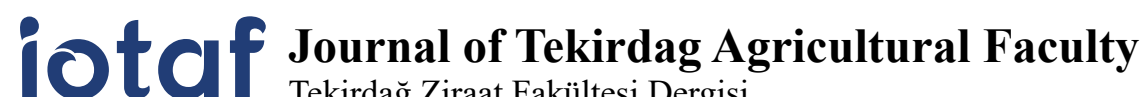 \\ Tekirdağ Ziraat Fakültesi Dergisi
}

Ocak/January 2019, 16(1)

Başvuru/Received: 01/02/18

Kabul/Accepted: 22/02/18

DOI: $10.33462 /$ jotaf.516991

http://dergipark.gov.tr/jotaf

http://jotaf.nku.edu.tr/

\section{Bazı Korunga (Onobrychis viciifolia) Çeşit ve Popülasyonlarının Mikrosatellit Belirteçleri Kullanılarak Genetik Karakterizasyonu*}

\author{
Genetic Characterization of Sainfoin (Onobrychis viciifolia) Varieties and Populations Using \\ Microsatellite Markers
}

\section{Selman ÖZKAN ${ }^{1}$, Behiye Banu BİLGEN ${ }^{2 * *}$}

\begin{abstract}
$\ddot{O} \mathbf{z}$
Ülkemizin özellikle İç ve Doğu Anadolu bölgelerinde yaygın bir şekilde yetiştiriciliği yapılan korunga (Onobrychis viciifolia Scop.) hayvan beslenmesinde, toprak yapısını iyileştirmede ve arılar için nektar kaynağı olarak önemli bir baklagildir. Bu çalışmada ülkemizin tescilli çeşitleri Özerbey ve Lütfübey’de, Kırşehir bölgesinden elde edilmiş iki yerel populasyonda (Kırşehir-1, Kırşehir-2) ve Bulgaristan'a ait Pleven populasyonunda 10 SSR lokusu kullanılarak çeşit ve populasyonların genetik yapısı incelenmiştir. Çalışmada kullanılan 10 SSR lokusunun tamamı polimorfik olarak saptanmıştır. Analiz edilen 91 örnekte toplam 68 allel tespit edilmiştir. Genetik çeşitlilik parametrelerinden, lokus başına düşen ortalama allel sayısı $(\mathrm{Na}=1.365)$, etkili allel sayısı $(\mathrm{Ne}=1.348)$, Shannon Sabiti $(\mathrm{I}=0.322)$, Nei'nin genetik çeşitlilik değeri $(\mathrm{h}=0.210)$ ve Nei'nin tarafsız çeşitlilik değeri (uh=0.222) hesaplanmıştır. Populasyonların genetik çeşitliliğinin büyük oranda (\%92) populasyon içerisinde olduğu, populasyonlar arası çeşitliliğin ise çok düşük olduğu (\%8) gözlenmiştir. Çalışma sonucunda elde edilen UPGMA dendrogramına göre birbirine yakın bulunan Özerbey ve Lütfübey bir grup, Pleven ve Kırşehir-2 ayrı bir grup olarak belirlenmiştir. Elde edilen sonuçlar türün genetik yapısı hakkında önemli bilgiler vermiştir.
\end{abstract}

Anahtar Kelimeler: Baklagiller, Genetik çeşitlilik, Moleküler belirteçler, Onobrychis viciifolia, SSR

\begin{abstract}
The sainfoin (Onobrychis viciifolia Scop.), which is widely grown in our country especially in the Central and Eastern Anatolian regions, is used for animal feed, improving the structure of soil and nectar source for bees. In this study, genetic structure of two cultivars (Özerbey and Lütfübey) and three populations (Pleven, Kırşehir-1 and Kırşehir-2) were investigated using 10 SSR loci. All of the SSR loci used in the study were polymorphic. A total of 68 alleles were identified in 91 samples analyzed. Genetic diversity parameters such as; mean number of alleles per locus $(\mathrm{Na}=1.365)$, effective allele number $(\mathrm{Ne}=1.348)$, Shannon information index $(\mathrm{I}=0.322)$, Nei's genetic diversity level $(\mathrm{h}=0.210)$, and Nei's unbiased genetic diversity level (uh=0.222) were calculated. It was observed that the genetic diversity of the populations was mainly due to within population variation (92\%) and the remaining portion was due to variation between populations (8\%). According to the UPGMA dendrogram obtained from the study, Özerbey and Lütfübey occurred in one cluster, Pleven and Kırşehir-2 populations occurred in the second cluster. The results obtained from this study provided important information on the genetic structure of the studied sainfoin populations.
\end{abstract}

Keywords: Fabaceae, Genetic diversity, Molecular markers, Onobrychis viciifolia, SSR

\footnotetext{
2**Sorumlu Yazar/Corresponding Author: Behiye Banu Bilgen, Namık Kemal Üniversitesi, Fen Bilimleri Enstitüsü, Tarımsal Biyoteknoloji Anabilim dalı, Tekirdağ. E-mail: bbilgen@nku.edu.tr, (D) OrcID: 0000-0001-8323-2509

'Selman Özkan, Namık Kemal Üniversitesi, Ziraat Fakültesi, Tarımsal Biyoteknoloji Bölümü, Tekirdağ, E-mail: selman.ozkan54@gmail.com. Atıf/Citation: Özkan, S., Bilgen, B.B. Bazı korunga (Onobrychis viciifolia) çeşit ve popülasyonlarının mikrosatellit belirteçleri kullanılarak genetik karakterizasyonu. Tekirdăg Ziraat Fakültesi Dergisi, 16(1), 51-60.

*Bu makale Selman ÖZKAN'ın yüksek lisans tezinden üretilmiştir.
} 


\section{Extended Summary}

The genus Onobrychis belonging to Fabaceae family includes approximately 130 species. Cultivated sainfoin is an allotetraploid species $(2 n=4 x=28)$. Eastern Mediterranean region and western Asia are the main biodiversity centers for Onobrychis viciifolia. The sainfoin (Onobrychis viciifolia Scop.), which is widely grown in our country especially in the Central and Eastern Anatolian regions, is used for animal feed, improving the structure of soil and nectar source for bees. "Sainfoin' word is originated from the two French words "sain" and "foin" that means "healthy hay". It is characterized by high contents of condensed tannins and these tannins support protein digestion in some grazing animals. Moreover, sainfoin has anthelminthic effect due to containing tannins and secondary compounds. In Turkey, around 70 sainfoin species are grown naturally and 27 of them are reported to be endemic to our country. The molecular studies about genetic characterization, genetic diversity, molecular phylogeny, transcriptome analysis, gene transfer, and cloning started rapidly in the 2000s. Many researchers have carried out different studies (agro-morphological, biological, cytological, phenological, genetic characterization, gene transfer etc.) in various countries with the sainfoin. Although there are not enough number of microsatellite markers specifically designed for Onobrychis species, there are some studies in the literature about the genetic characterization of sainfoin genotypes with the use of markers designed for other legume species. Generally AFLP, SSR, ISSR, RAPD, ITS region, trnL-trnF region and SRAP markers designed for other legume species mainly used for molecular studies in sainfoin populations. Kempf et al. (2016) reported new novel SSR markers firstly in diverse sainfoin germplasm and then these SSR markers are being used in genetic diversity studies. The main aims of our study were (1) to determine the genetic structure of the studied sainfoin cultivars and populations by SSR analysis; (2) to estimate the genetic diversity parameters; (3) to compare acquired information about genetic diversity with the other studies in the literature.

Fresh leaves of around 20 individuals from each of the varieties (Özerbey and Lütfübey) and populations (Pleven, Kırşehir-1, and Kırşehir-2) of $O$. viciifolia were used for DNA extraction. Fresh leaves were stored at $-80^{\circ} \mathrm{C}$ until DNA isolation. The leaves belonging to individuals of each population was ground with a ball mill before DNA isolation. Total genomic DNA was isolated by Doyle and Doyle (1990) CTAB based protocol with slight modifications. The DNA in samples was quantified with Qubit ${ }^{\circledR} 2.0$ Fluorometer and also controlled by electrophoresis on $1 \%$ agarose gels. The extracted DNA samples stored at $+4^{\circ} \mathrm{C}$ for further use. In this study, genetic structure of two varieties and three populations were investigated using 10 SSR loci (OVK036, OVK094, OVK125, OVM033, OVK161, OVM125, OVK046, OVM061, OVK174, and OVK101) selected from developed 101 microsatellite markers (SSRs) specific to $O$. viciifolia from the study of Kempf et al. (2016). M13 tail protocol developed by Schuelke (2000) was used because of its economical nature for the determination of PCR fragment size. M13 primers were 5' end-labeled with fluorochromes (PET, NED, VIC, and FAM). The PCR amplifications were performed as described in Kempf et al. (2016). The DNA amplifications by PCR were carried out by using the Applied Biosystems ${ }^{\circledR}$ ProFlex ${ }^{\mathrm{TM}}$ PCR System Thermal Cycler. Amplified allele fragments were separated using a 3500 Genetic Analyzer and their size was determined with GeneMapper software version 5.0. For the analysis of SSR data, allelic frequencies, effective numbers of alleles $\left(\mathrm{N}_{\mathrm{e}}\right)$, polymorphism level, Shannon's information index (I), Nei's genetic diversity level ( $\mathrm{h}$ and $\mathrm{uh}$ ) and polymorphic information contents (PIC) were calculated using the software GenAlEx Version 6.3 (Peakall and Smouse, 2006) and (Roldan-Ruiz et al. 2000). Cluster analysis was performed by using the unweighted pair group method (UPGMA). UPGMA tree was constructed by Molecular Evolutionary Genetics Analysis Version 6.0 (MEGA6) software (Tamura et al., 2013).

All of the SSR loci used in the study were polymorphic. Using 10 SSR, 68 alleles with a mean of 6.8 alleles per population and locus were identified in 91 samples analyzed. Considering five studied sainfoin groups, OVK046 has the highest number of alleles (11 alleles) and the locus OVK174 has the lowest number of alleles (three alleles). OVK161 has 9 alleles, OVK036 and OVK094 have 8 alleles, OVM033 and OVM061 have 7 alleles, OVK101 has 6 alleles, OVK125 has 5 alleles, OVM125 has 4 alleles. There were totally 16 private alleles in studied sainfoin varieties and populations. Özerbey has one private allele for OVK101, Lütfübey has two private alleles for OVK036 and OVK161. Pleven has seven private alleles for OVK036, OVK094, OVM033, OVK046, OVM061, OVK174 and OVK101, Kırşehir-1 has 2 private alleles for OVK036 and OVK046, and Kırşehir-2 has 4 private alleles for OVK094, OVM033, OVK161 and OVK046. When we consider all of the studied sainfoin individuals, the overall mean PIC (polymorphic information contents) value of studied SSR loci was estimated as 0.210. The highest mean PIC value was observed in OVK125 primer. The lowest mean PIC value was observed in OVK161 primer. PIC estimation results in both this study and Kempf et al. (2016) study were consistent with each other.

Genetic diversity parameters such as; mean number of alleles per locus $\left(\mathrm{N}_{\mathrm{a}}=1.365\right)$, effective allele number $\left(\mathrm{N}_{\mathrm{e}}=1.348\right)$, Shannon information index $(\mathrm{I}=0.322)$, Nei's genetic diversity level $(\mathrm{h}=0.210)$, and Nei's unbiased 
genetic diversity level ( $\mathrm{hh}=0.222$ ) were calculated. Overall mean Shannon's Information index (I) was estimated as 0.322 , the highest in Pleven population (0.385) and lowest in Kurşehir-1 population $(0.251)$. The highest Nei's (1987) unbiased genetic diversity (uh) level was calculated as 0.269 in Pleven population, whereas the lowest value was 0.170 in Kırşehir-1 population. It was observed that the genetic diversity of the populations was mainly due to within population variation $(92 \%)$ and the remaining portion was due to variation between populations $(8 \%)$. The AMOVA result shows that there is a wide range of genetic diversity within the populations. Nei's (1987) genetic similarity coefficient ranged from 0.943 (Pleven-Kırșehir-1) to 0.982 (Özerbey-Lütfübey) among all possible population pairs. When all population pairs were taken into consideration, the mean genetic distance value was 0.038 and the mean genetic similarity value was calculated as 0.963 . According to the UPGMA dendrogram obtained from the study, Özerbey and Lütfübey occurred in one cluster, Pleven and Kırşehir-2 populations occurred in the second cluster. According to the results obtained, it is seen that Kırşehir-1 population is genetically diverse slightly than the other sainfoin varieties and populations.

Allelic richness and availability of population-specific alleles (private alleles) are the important basic diversity measurement tools. Determined high level of private alleles and allelic richness may be regarded as a clear expression of genetic diversity of individuals. Genetic characterization of existing germplasm is significant in order to conserve sainfoin genetic resources, reveal genetic potential and provide new alternative approaches for further breeding programs. The results obtained from this study provided important information on the genetic structure of the studied sainfoin populations. The SSR primers used in this study were first SSR primers which are specific to $O$. viciifolia (Kempf et al. 2016). This study, which we used sainfoin specific SSR loci, provided information about the genetic diversity of the species, inter and intra population variation, and also will be the significant reference for subsequent studies. It will also inform us about the genetic structure of the species and guide us to the biodiversity that sainfoin have. With the molecular studies, we can reveal the hidden information in the genomes of plants that can be grown especially at marginal habitats, therefore the breeding studies based on the genetic structure knowledge of studied species will be planned in order to develop new varieties or cultivars. 
İnsanoğlunun dengeli, yeterli ve sağlıklı beslenebilmesi bakımından hayvansal kaynaklı gıdalar büyük önem arz etmektedir. Hayvansal ürünlerin üretim aşamasında yapılan masrafların \%70'lik gibi büyük bir kısmını oluşturan yem ve besleme masrafları, işletmenin karlılı̆̆ını önemli bir ölçüde etkilemektedir. Bu nedenle hem nispeten daha ucuz hem de ruminant hayvanların sindirim faaliyetlerini olumlu yönde etkileyen kaba yemler ve kaba yemleri oluşturan bitkiler büyük önem arz etmektedir (Özkan ve Demirbağ, 2016). Korunga (Onobrychis viciifolia Scop.), Baklagiller (Fabaceae) familyasına ait, farklı ekolojik koşullarda yetişebilen, yabancı döllenen faydalı çok yıllık bir yem bitkisi türüdür (Elçi, 2005). Korunganın yayılma alanı içerisinde yer alan ülkemizde 70 kadar korunga türü doğal olarak yetişmektedir ve tespit edilen bu türlerden 27 tanesinin endemik tür olduğu bildirilmiştir (Aktoklu, 1995; Açıkgöz, 2001). Ülkemizde en fazla korunga yetiştiriciliğgi Doğu Anadolu ve İç Anadolu bölgelerimizde yapılmaktadır. Kıraç ve kireçli toprak yapısındaki alanlarda yetiştirilebilecek en uygun yem bitkisi olan korunga, ot kalitesi ve hayvan performansı açısından verimli olması, hayvanlarda şişme yapmaması, yapay meralarda ve/ veya sslah çalışması yapılan meralarda geniş bir kullanım alanının bulunması, içerdiği tanenler ve ikincil bileşikler nedeniyle antihelmintik etki göstermesi, içerdiği yüksek miktardaki nektar ve polen nedeniyle iyi bir arı merası olarak işlev görmesi gibi birçok özellik bakımından önemli bir bitkidir (Tosun, 1992; Özbek, 2011; Özalp ve Temel, 2016).

Korunga bitkisi ile ilgili moleküler çalışmalar 2000'li yıllarda gelişen teknoloji ile hızlanmıştır. Onobrychis türü için spesifik olarak dizayn edilmiş mikrosatellit belirteçleri yayınlanana kadar diğer baklagil türlerinde dizayn edilmiş belirteçlerin korunga türlerinde denenmesine yönelik çalışmalar literatürde mevcuttur. Carbonero (2011) tarafından yapılan tez çalışmasında, 291 farklı korunga aksesyonu hem morfolojik hem de moleküler tabanlı olarak araştırılmıştır. Aksesyonlar arası çeşitliliğin belirlenmesi için AFLP ve SSR belirteçleri kullanılmış̧ır. Türün moleküler yapısı ve çeşitliliği ile ilgili ülkemizde yapılan çalışmaların başında, Avcı ve ark. (2014) tarafından Türkiye'den örneklenen 58 Onobrychis taksonu üzerinde yapılan çalışmada yakın akraba türlerine ait 95 SSR lokusu denenmiş, bu lokuslardan 14 tanesi genetik çeşitliliğin belirlenmesi amacı ile kullanılmıştır. Demdoum ve ark. (2012) tarafından yapılan araştırmada Medicago trancatula'dan seçilen 24 SSR primeri ve Glysine max'dan seçilen 3 SSR primeri kullanılarak 23 korunga aksesyonunda genetik benzerlik oranı belirlenmiştir.

$\mathrm{Bu}$ çalışma kapsamında; farklı korunga çeşit ve populasyonlarının SSR lokusları açısından genetik yapıları ortaya konulmuş, çalışılan çeşit ve populasyonların genetik parametrelerinin tahmin edilmesi ile genetik çeşitlilik düzeyleri belirlenmiş ve belirlenen genetik çeşitlilik düzeyleri literatürde mevcut olan diğer çalışmalarla karşılaştırılmıştır. Çalışmadan elde edilen sonuçların yüksek adaptasyon kabiliyeti ve performansa sahip yeni korunga çeşitlerinin geliştirilmesinde kullanılacak en uygun sslah stratejilerinin belirlenmesinde sslahçılara yardımcı olacağı düşünülmektedir.

\section{Bitki materyali}

\section{Materyal ve Yöntem}

Bu çalışmada, bitki materyali olarak ülkemizin tescilli 2 korunga çeşidi (Özerbey ve Lütfübey) ve biri yurtdışı kaynaklı (Pleven populasyonu) diğer ikisi yurtiçi kaynaklı (Kırşehir-1 ve Kırşehir-2 populasyonları) 3 korunga populasyonu kullanılmıştır.

\section{DNA izolasyonu}

Korunga (O. viciifolia) bitkisinden saf DNA elde etmek içerdiği yüksek tanen ve ikincil bileşikler nedeniyle güçleşmektedir. Kaliteli ve iyi miktarda DNA izolasyonu yapabilmek için çalışmada birden çok izolasyon metodu ve modifikasyonları denenmiştir (Doyle ve Doyle, 1990; Souza ve ark., 2012; Healey ve ark., 2014). DNA izolasyonu optimizasyonları sonucunda Doyle ve Doyle (1990) metodu bazı modifikasyonlarla kullanılmıştır. Tarladan toplanan çeşit ve populasyonlara ait genç ve taze yaprak örnekleri Retsch ${ }^{\circledR}$ MM4000 homojenizatör yardımıyla ezilmiş, ardından DNA izolasyonu gerçekleştirilmiştir. İzole edilen DNA örneklerinin kalite ve miktar tayinleri Nanodrop ${ }^{\circledR} 1000$ spektrofotometre cihazı yardımıyla Akdeniz Üniversitesi, Fen Fakültesi, Biyoloji Bölümü, Bitki Biyoteknolojisi Laboratuvarında ve Tekirdağ Bağcılık Araştırma Enstitüsü Moleküler Genetik Laboratuvarında yapılmış ve \%1'lik agaroz jel içinde 1X TBE tamponunda 90 Voltta 45 dk yürütülerek UV 1şık altında Gel Imaging System Vilber Lourmat Quantum ST5 ile görüntülenmiştir. Elde edilen DNA örnekleri PCR işlemleri yapılıncaya kadar $+4^{\circ} \mathrm{C}$ 'de buzdolabında muhafaza edilmiştir.

\section{SSR analizleri}

Bu çalışmada kullanılmak üzere belirlenen 10 SSR primeri Kempf ve ark. (2016) tarafından korungaya spesifik olarak ilk geliştirilen 101 SSR primeri içinden seçilmiştir. Çalışmada, ekonomik olması sebebiyle Schuelke (2000) tarafından geliştirilen M13 primer işaretleme yöntemi kullanılmıştır. DNA amplifikasyonları, SSR primerleri için PCR analizleri Kempf ve ark. (2016)'nın çalışmasındaki reaksiyon koşullarında ve PCR döngülerinde denenmiş, ayrıca laboratuvar şartlarımıza uygun gerekli optimizasyonları yapılmıştır. PCR bantlarının istenilen bölgede olup 
olmadığını ve spesifik bağlanmaların olup olmadığını kontrol etmek için \%2'lik agaroz jelde 1 X TBE tamponunda 110 Voltta yaklaşık $120 \mathrm{dk}$ yürütülmüştür. Bantlar UV ışık altında Gel Imaning System Vilber Lourmat Quantum ST5 ile görüntülenmiştir. Elde edilen PCR ürünlerinin DNA parça (fragment) büyüklüklerini belirlemek için hizmet alımı yapılmıştır. Çalışılan çeşit ve populasyonlardaki örneklerden DNA parça (fragment) analizlerinin sonuçları laboratuvarımızda GeneMapper Software 5.0 (Applied Biosystems) yazılımı ile değerlendirilmiş ve primerlerin sahip olduğu allellerin büyüklükleri tespit edilmiştir. Verilerin istatistiki analizleri çeşit ve populasyonların genetik yapısını belirleyebilmek için her birinde, polimorfik lokuslar ve yüzdeleri, polimorfik lokuslarda gözlenen allel sayısı (Na), etkili allel saysı (Ne), Nei (1987)'nin genetik çeşitlilik değeri (h), Nei (1987)'nin tarafsı genetik çeşitlilik değeri (uh), Shannon sabiti (I) ve standart hataları hesaplanmıştır. Polimorfik bilgi içeriği (PIC) RoldanRuiz ve ark. (2000)'nın geliştirdikleri formül kullanılarak hesaplanmıştır. İstatistiki analizler için elde edilen veriler GenAlEx (Version 6.5) (Peakall ve Smouse, 2006) istatistik yazılım programı kullanılarak yapılmıştır. Basamaklı mutasyon modeline göre moleküler varyans analizinde (AMOVA) GenAlEx (Version 6.5) istatistik programından yararlanılmıştır. Nei’nin populasyonlar arasındaki genetik farklılaşma düzeyini tespit etmek için Nei'nin tarafsız genetik mesafe ve benzerlik katsayıları hesaplanmıştır (Nei, 1987). Sonuçların daha anlaşılır bir şekilde sergilenebilmesi için Nei'nin tarafsız genetik mesafe katsayısı ve UPGMA (Unweighted Pair-Group Method with Arithmetic Average) kümelendirme yöntemi kullanarak bir dendrogram oluşturulmuştur (Sneath ve Sokal, 1973). Bu dendrogramın oluşturulmasında MEGA6: Molecular Evolutionary Genetics Analysis Version 6.0 programından yararlanılmıştır (Tamura ve ark., 2013). polimorfik olarak saptanmış ve primerlere ait bilgiler Çizelge 1'de verilmiştir.

Çizelge 1. Çalışmada kullanılan 10 SSR primerine ait genetik parametreler

Table 1. Genetic parameters of 10 SSR primers used in the study

\begin{tabular}{cccccccccc}
\hline Primer & Ort. PIC & Min. PIC & Maks. PIC & NoA & $\begin{array}{c}\text { NoA } \\
\text { Priv. }\end{array}$ & Ort. AF & Min. AF & Maks. AF & Bant Aralığ1 \\
\hline OVK036 & 0.193 & 0.095 & 0.492 & 8 & 3 & 0.267 & 0.05 & 0.875 & $141-173$ \\
\hline OVK094 & 0.194 & 0.095 & 0.487 & 8 & 2 & 0.128 & 0.05 & 0.421 & $234-257$ \\
\hline OVK125 & 0.296 & 0.1 & 0.494 & 5 & 0 & 0.377 & 0.053 & 1 & $196-212$ \\
\hline OVM033 & 0.241 & 0.095 & 0.5 & 7 & 2 & 0.207 & 0.05 & 0.722 & $306-324$ \\
\hline OVK161 & 0.147 & 0.095 & 0.5 & 9 & 2 & 0.131 & 0.05 & 0.75 & $206-274$ \\
\hline OVM125 & 0.293 & 0.095 & 0.5 & 4 & 0 & 0.345 & 0.05 & 0.8 & $167-181$ \\
\hline OVK046 & 0.215 & 0.095 & 0.5 & 11 & 3 & 0.23 & 0.05 & 0.9 & $128-172$ \\
\hline OVM061 & 0.208 & 0.095 & 0.494 & 7 & 1 & 0.297 & 0.05 & 0.947 & $151-179$ \\
\hline OVK174 & 0.245 & 0.117 & 0.499 & 3 & 1 & 0.439 & 0.063 & 1 & $247-252$ \\
\hline OVK101 & 0.154 & 0.095 & 0.488 & 6 & 2 & 0.113 & 0.05 & 0.632 & $360-388$ \\
\hline
\end{tabular}

$(\mathrm{PIC}=$ Polimorfik bilgi içeriği, Ort. $=$ Ortalama, Min. $=$ Minimum, Maks. $=$ Maksimum, NoA $=$ Gözlenen allel sayıs1, NoA Priv. $=$ Populasyona özgü allel sayısı, $\mathrm{AF}=$ Allel frekansı)

\section{Bulgular}

Çalışılan bütün populasyonları bir bütün olarak değerlendirdiğimizde 10 SSR primerinin tamamı Çalışılan O. viciifolia çeşit ve populasyonlarında kullanılan 10 SSR lokusu için toplam 68 allel tespit edilmiştir. $\mathrm{Bu}$ çalışmada kullanılan her bir lokusdaki allellerin, araştırılan tüm populasyonlara göre dağı̆lımlarına bakıldığında bazı allellerin yalnızca bir populasyona özgü allel olduğu (private allel) gözlenmiştir. Populasyona özgü alleller (private allel) Özerbey çeşidinde 1 allel, Lütfübey çeşidinde 2 allel, Pleven populasyonunda 7 allel, Kırşehir-1 populasyonunda 2 allel ve Kırşehir-2 populasyonunda 4 allel olarak tespit edilmiştir. Analiz edilen bütün örnekler ele alındığında ortalama Shannon sabiti (I) $0.322 \pm 0.014$ olarak tespit edilmiş̧tir. Shannon sabiti (I), 0.385 değeri ile en yüksek Pleven populasyonunda, 0.251 değeri ile en düşük Kırşehir-1 populasyonunda hesaplanmıştır. Nei (1987)'nin genetik çeşitlilik (h) ve tarafsız genetik çeşitlilik değeri (uh) her çeşit ve populasyon için ayrı ayrı hesaplanmıştır. Nei (1987)'nin genetik çeşitlilik değeri (h) ortalama $0.210 \pm 0.010$ olarak hesaplanmış, en yüksek değer Pleven populasyonunda (0.252), en düşük değer ise Kurşehir-1 populasyonunda (0.161) gözlenmiştir. Nei (1987)'nin tarafsız genetik çeşitlilik değeri (uh) ortalama $0.222 \pm 0.011$ olarak hesaplanmış, en yüksek değer Pleven populasyonunda (0.269), en düşük değer ise Kırşehir-1 populasyonunda ( 0.170$)$ belirlenmiştir (Çizelge 2). Çalışmada kullandığımız 10 SSR belirtecine ait ortalama polimorfik bilgi içeriği (PIC) değeri, populasyon bazında değerlendirdiğimizde, Özerbey çeşidinde 0.220 , Lütfübey çeşidinde 0.202 , Pleven populasyonunda 0.252 , Kırşehir-1 populasyonunda 0.161 ve Kırşehir-2 populasyonunda ise 0.213 olarak hesaplanmıştır. Analiz edilen tüm örnekleri bir bütün olarak ele aldığımızda ortalama PIC değeri 0.210 olarak tespit edilmiş̧tir (Çizelge 2). 
Çizelge 2. Korunga çeşit ve populasyonlarına ait genetik çeşitlilik parametreleri

Table 2. Genetic diversity parameters of sainfoin varieties and populations

\begin{tabular}{|c|c|c|c|c|c|c|c|c|}
\hline $\begin{array}{c}\text { Çeşit ve } \\
\text { Populasyonlar }\end{array}$ & $\mathrm{N}$ & AS & $\mathrm{Na}$ & $\mathrm{Ne}$ & I & $\mathrm{h}$ & uh & PIC \\
\hline & & & 1.338 & 1.373 & 0.332 & 0.22 & 0.232 & \\
\hline \multirow[t]{2}{*}{ Özerbey } & 19 & 46 & $( \pm 0.114)$ & $( \pm 0.045)$ & $( \pm 0.034)$ & $( \pm 0.024)$ & $( \pm 0.025)$ & 0.22 \\
\hline & & & 1.294 & 1.333 & 0.311 & 0.202 & 0.214 & \\
\hline \multirow[t]{2}{*}{ Lütfübey } & 18 & 44 & $( \pm 0.117)$ & $( \pm 0.042)$ & $( \pm 0.032)$ & $( \pm 0.023)$ & $( \pm 0.024)$ & 0.202 \\
\hline & & & 1.603 & 1.421 & 0.385 & 0.252 & 0.269 & \\
\hline \multirow[t]{2}{*}{ Pleven } & 16 & 55 & $( \pm 0.096)$ & $( \pm 0.043)$ & $( \pm 0.030)$ & $( \pm 0.022)$ & $( \pm 0.023)$ & 0.252 \\
\hline & & & 1.147 & 1.264 & 0.251 & 0.161 & 0.17 & \\
\hline \multirow[t]{2}{*}{ Kırşehir-1 } & 20 & 39 & $( \pm 0.121)$ & $( \pm 0.041)$ & $( \pm 0.032)$ & $( \pm 0.022)$ & $( \pm 0.023)$ & 0.161 \\
\hline & & & 1.441 & 1.347 & 0.329 & 0.213 & 0.225 & \\
\hline \multirow[t]{2}{*}{ Kırkşehir 2} & 18 & 49 & $( \pm 0.110)$ & $( \pm 0.041)$ & $( \pm 0.031)$ & $( \pm 0.022)$ & $( \pm 0.023)$ & 0.213 \\
\hline & 18.2 & & 1.365 & 1.348 & 0.322 & 0.21 & 0.222 & \\
\hline Ortalama & $( \pm 0.072)$ & 46.6 & $( \pm 0.050)$ & $( \pm 0.019)$ & $( \pm 0.014)$ & $( \pm 0.010)$ & $( \pm 0.011)$ & 0.21 \\
\hline
\end{tabular}

( $\mathrm{N}=$ örnek sayısı, $\mathrm{AS}=$ Toplam allel sayısı, $\mathrm{Na}=$ lokus başına düşen ortalama gözlenen allel sayısı, $\mathrm{Ne}=$ etkili allel sayısı, I = Shannon sabiti, h = Nei (1987)'nin genetik çeşitlilik değeri uh = Nei (1987)'nin tarafsız genetik çeşitlilik, PIC $=$ Polimorfik bilgi içeriği, \pm standart hata)

Basamaklı mutasyon modeline göre yapılan varyans analizi (AMOVA) sonuçlarına göre çalışılan beş korunga çeşit ve populasyonu arasındaki varyasyonun büyük oranda (\%92) populasyonlar içerisinde olduğu, populasyonlar arası çeşitliliğin düşük olduğu (\%8) gözlenmiştir (FST=0.076). Elde edilen sonuç korunga populasyonları içerisinde geniş bir genetik çeşitliliğin olduğunu göstermektedir. Nei’nin tarafsız genetik benzerlik ve genetik farklılık katsayısı kullanılarak populasyonlar arası genetik farklılaşmanın düzeyi belirlenmiştir (Nei 1987). Çalışma kapsamında kullanılan 10 SSR lokusuna ait bilgilere dayanarak elde edilen genetik benzerlik ve genetik mesafe değerleri Çizelge 3'de gösterilmiştir. Genetik benzerlik değerleri 0.943 ile 0.982 arasında değişim göstermektedir. En yüksek genetik benzerlik değeri Özerbey ve Lütfübey çeşitleri arasında, en düşük genetik benzerlik değeri ise Pleven ve Kırşehir-1 populasyonları arasında hesaplanmıştır. Tüm populasyon çiftleri göz önüne alındığında ortalama genetik mesafe değeri 0.038 ve ortalama genetik benzerlik değeri 0.963 olarak hesaplanmıştır. Çalışmada kullanılan korunga çeşit ve populasyonlarındaki genetik farklılaşmanın görsel bir grafik üzerinde görülmesi için Nei (1987)'nin genetik mesafe değerleri UPGMA kümelendirme yöntemi ile sınıflandırılmış ve dendrogram oluşturulmuştur (Şekil 1).

Çizelge 3. O. viciifolia çeşit ve populasyonları arasında Nei (1987)’ye göre hesaplanan genetik benzerlik ve genetik mesafe değerleri (sol alt diyagonal: genetik benzerlik, sağ üst diyagonal: genetik mesafe değerleri)

Table 3. Genetic similarity and genetic distance values calculated according to Nei (1987) between species and populations of $O$. viciifolia (left lower diagonal: genetic similarity values, right upper diagonal: genetic distance values)

\begin{tabular}{cccccc}
\hline Çeşit ve Populasyonlar & Özerbey & Lütfübey & Pleven & Kirşehir-1 & Kırşehir-2 \\
\hline Özerbey & $* * *$ & 0.018 & 0.039 & 0.055 & 0.032 \\
\hline Lütfübey & 0.982 & $* * *$ & 0.031 & 0.047 & 0.037 \\
\hline Pleven & 0.961 & 0.969 & $* * *$ & 0.058 & 0.025 \\
\hline Kırşehir-1 & 0.947 & 0.954 & 0.943 & $* * *$ & 0.037 \\
\hline Kurşehir-2 & 0.968 & 0.964 & 0.976 & 0.964 & $* * *$ \\
\hline
\end{tabular}




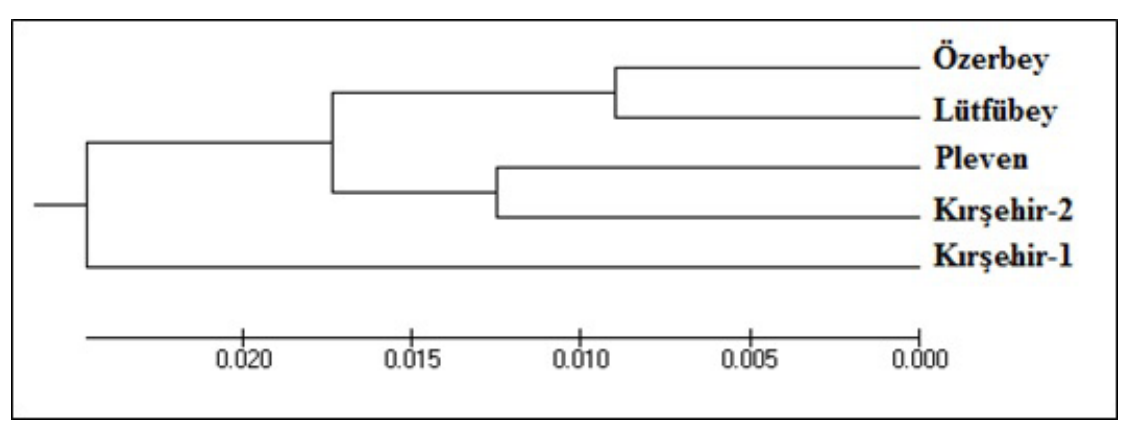

Şekil 1. O. viciifolia çeşit ve populasyonlarının Nei’nin (1987) genetik mesafe değerlerine göre oluşturdukları dendrogram

Figure 1. Dendrogram constructed using Nei's (1987) genetic distance values for O. viciifolia varieties and populations

\section{Tartışma ve Sonuç}

Korunga ile ilgili daha önce yapılan çalışmalara bakıldığında; türün agronomik, fizyolojik ve morfolojisi üzere birçok araştırma literatürde mevcuttur. Ancak türün moleküler genetiği ile ilgili çalışmalar nadirdir. Fakat gelişen teknoloji ve bilimdeki yeniliklerle birlikte 2000'li yıllardan sonra moleküler çalışmaların ivme kazandığı lakin yine de sınırlı sayıda çalışma olduğu görülmüştür. Yapmış olduğumuz çalışmada kullanılan 10 SSR lokusu, çalışılan beş korunga populasyonu bir bütün olarak ele alındığında hepsi polimorfik olarak tespit edilmiştir. Çalışmamızda 10 SSR lokusundan toplam 68 allel belirlenmiş, primer başına ortalama allel sayısı 6.8 olarak hesaplanmıştır. Benzer genetik çalışmalarla karşılaştıııldığında; Kempf ve ark. (2016)'nın 29 farklı aksesyondan 32 farklı bireyde 400 primer ile yaptıkları çalışmada, polimorfik 101 primer belirlenmiş, 1159 allel tespit edilmiş, 1154'ü polimorfizm göstermiştir. Kempf ve ark. (2016)'nın çalışmasında primer başına ortalama allel sayısı 11.4 olarak ve lokus başına düşen allel sayısı 2 ile 21 arasında bildirilmiştir. Bu çalışmada kullanılan SSR primerleri Kempf ve ark. (2016)'nın çalışmasından seçilmiş ve elde edilen sonuçların birbiri ile uyumlu olduğu görülmüştür. Avcı ve ark. (2014)'nın 58 Onobrychis taksonundan örneklenen bireylerde yapılan çalışmasında bezelye ve yoncadan geliştirilen belirteçler kullanılarak analizler yapılmış ve 18 SSR belirtecine ait 79 lokus ve 725 allel bildirilmiş̧tir. Ayrıca bu çalışmada lokus başına düşen allel sayısı 9.18 olarak belirtilmiştir. Demdoum ve ark. (2012)'nın yaptıkları çalışmada genetik karşılaştırma, M. trancatula ve G. max türlerine ait 27 EST-SSR primeri kullanılarak yapılmıştır. Bu çalışmada kullanılan 27 EST-SSR primerinin 22 tanesinin (\%81) korungada PCR çoğaltımının yapılabildiği ve 14 tanesinin polimorfik olduğu bildirilmiştir. Aynı çalışmada genetik yapının belirlenmesi için seçilen 6 SSR belirtecinde toplam 35 allel, lokus başına düşen allel sayısı 5.83 olarak tespit edilmiş̧ir.

Tetraploid türlerde SSR allellerinin hangi oranlarda bulunduğunun (dozaj) belirlenmesi zordur. Kapiller elektroforez kullanılarak elde edilen SSR allelerinin dozajlarını belirlemek eğer birey belirli bir SSR lokusunda 4 farklı allelden daha az allel taşıyorsa genellikle imkânsızdır. Geleneksel olarak hesaplanan PIC değeri formülü (Botstein ve ark., 1980) diploid türler için geliştirilmiştir. Tetraploid türler için farklı allel (1-4 allel) dozlarından dolayı allellerin varlığından veya yokluğundan yola çıkarak allel frekansı hesaplanması güçtür. Bu nedenle diploid türler için geliştirilen formüller korunga gibi tetraploid türlerde kullanılamamaktadır. Bu nedenle, tetraploid türler için PIC değeri, her bir allellin var/yok sayımı göz önüne alınarak oluşturulmuş Roldan-Ruiz ve ark. (2000)'in geliştirdiği formül ile hesaplanmaktadır. Bu formüle göre ulaşılan maksimum PIC değeri 0.5 'dir, bu da populasyonun \%50'sinde bulunan allellere karşılık gelir. Küçük PIC değeri, ya bol bulunan allel ya da nadir allellere karşıllık gelir (Kempf ve ark. 2016). Kempf ve ark. (2016) 101 SSR lokusunda ortalama PIC değerini 0.14 (OVK141) ile 0.36 (OVK101) arasında saptamıştır. Çalışmada en düşük PIC değerinin 0 (OVK042, OVK172, OVM031, OVM072 ve OVM100) ile 0.17 (OVK131) arasında, en yüksek PIC değerinin ise 0.3 (OVK172) ile 0.5 (16 farklı lokus) arasında olduğu hesaplanmıştır. Bu çalışma da elde edilen sonuçlar ile Kempf ve ark. (2016)'nın çalışmasındaki PIC değerleri birbiri ile uyumludur (Çizelge 1). Demdoum ve ark. (2012)'nın yaptıkları araştırmada Medicago trancatula ve Glysine max'dan geliştirilen 6 primere ait PIC değerleri 0.45 ile 0.85 (ortalama 0.72) arasında bulunmuştur. Zarrabian ve Majidi (2015) tarafindan 33 Onobrychis türüne ait 102 aksesyon üzerinde yapılan çalışmada 22 ISSR primerine ait PIC değerleri 0.34 ile 0.47 arasında hesaplanmıştır. Bhattarai (2017) yaptığı tez çalışmasında farklı ülkelerden 38 korunga aksesyonunda 5 AFLP primeriyle yaptı̆̆ı çalışmada PIC değerini 0.126 ile 0.196 arasında hesaplamıştır. Çalışmada AFLP belirteçlerinin dominant bir belirteç olması ve bu nedenle homozigot ve heterozigot alelleri ayırt edememesine rağmen, genetik çeşitlilik ve genotipler arasındaki ilişkileri bilinen türlerde yeterli genomik bilgi yokluğunda kullanılabileceği bildirilmiştir.

Çalışılan lokuslardaki genetik çeşitliliğin en temel ölçülerinden biri allellik zenginliğin ve populasyona özgü allellerin belirlenmesidir. Populasyonlarda belirlenen çok sayıda populasyona özgü allel, bireylerin genetik farklılığının açıkça bir ifadesi olarak kabul görebilir. Çalışmamızda tüm primerlerde populasyonlara özgü 
(private) allel tespit edilmiştir. Kempf ve ark. (2016)'nın çalışmasında 101 SSR primerine ait 250 adet bireye özgü (private) allel tespit edilmiştir. Kempf ve ark. (2016)'nın çalışmasında (bu çalışmada ortak olarak kullanılan) 10 SSR primeri için toplam 18 bireye özgü allel belirlenmiştir. Kempf ve ark. (2016)'nın çalışmasında OVK036 primerinde populasyona özgü allel gözlenmezken, bizim çalışmamızda toplam 3 adet populasyona özgü (private) allel tespit edilmiş̧ir.

Çalışılan çeşit ve populasyonlar için genetik çeşitlilik parametrelerinden bir tanesi olan Shannon sabiti (I) en yüksek Pleven populasyonunda $(0.385 \pm 0.030)$, en düşük ise Kırşehir-1 $(0.251 \pm 0.032)$ populasyonunda hesaplanmıştır. Nosrati ve ark. (2012)'nın farklı bölgelerden topladıkları 5 yabani korunga populasyonunda 5 RAPD primerleriyle yaptığı çalışmada, I değeri 0.364 ile 0.461 arasında hesaplanmıştır. Nosrati ve ark. (2016)'nın ISSR primerleri ile yaptıkları çalışmada, I değeri 0.181 ile 0.277 arasında hesaplanmıştır. Zarrabian ve ark. (2013)'nın 46 İran ve 34 egzotik olmak üzere toplam 80 korunga aksesyonunda yaptığı çalışmada I değeri 0.33 ile 0.57 arasında hesaplanmış, en fazla çeşitliliğin İran grubu Zagros Dağlarında (0.44), egzotik bölge aksesyonlarından Asya ve Doğu Avrupa aksesyonlarında (0.45) olduğu belirlenmiştir. Çalışmanın sonuçlarına bakıldığında Avrupa'daki korunga aksesyonlarının Asya ve Doğu Avrupa arasındaki bir bölgeden geldiği hipotezinin desteklendiği görülmüştür.

Bu çalışma kapsamında hesaplanan Nei'nin genetik çeşitlilik değeri (h) 0.161 (Kırşehir-1) ile 0.252 (Pleven) arasında hesaplanmıştır. Hejrankesh ve ark. (2014)'nın 10 İran yerel korunga çeşitlerinde 90 RAPD belirteci ile yaptıkları çalışmada, h değeri 0.300 ile 0.343 arasında bildirilmişstir. Nosrati ve ark. (2016)'nın ISSR belirteçleriyle 5 İran populasyonunda yaptıkları çalışmada, h değerinin 0.118 ile 0.179 arasında olduğu bildirilmiştir. Nosrati ve ark. (2012)'nın RAPD primerleriyle 5 korunga populasyonunda yaptıkları çalışmada h değeri 0.246 ile 0.318 arasında bulunmuştur. Avcı ve ark. (2014) tarafindan yapılan çalışmada Nei'nin genetik çeşitlilik değeri 0.140 ile 0.307 arasında hesaplanmıştır. Bu çalışmadan elde edilen sonuçları benzer çalışmalarla mukayese ettiğimizde çalışılan populasyon sayılarının ve belirteç tipinin farklı olması $\mathrm{h}$ değerinin bazı çalışmalardan yüksek/düşük veya yakın olarak hesaplanmasını sağlamıştır.

Basamaklı mutasyon modeline göre elde edilen verilerin incelenmesiyle yapmış olduğumuz moleküler varyans analizi (AMOVA) sonuçlarına göre, çalışılan beş korunga çeşit ve populasyonları arasındaki genetik çeşitlilik \%92 oranında populasyonlar içerisindedir. Hejrankesh ve ark. (2014)'nın İran yerel çeşitlerinde yaptıkları çalışmada moleküler varyans analizi sonuçlarına göre genetik çeşitliliğin büyük oranda populasyon içinde olduğu (\%83.87), populasyonlar arası çeşitliliğin az olduğu görülmüştür (\%16.13). Hejrankesh ve ark. (2014)'nın çalışmasında yerel çeşitlere ait popualsyonlar içi çeşitliliğin yüksek olması korunganın yabancı döllenmesi ve tozlayıcı böceklerin korungaları tozlamasıyla meydana geldiği bildirilmiştir. Zarrabian ve ark. (2013)'nın Dünya koleksiyonlarında ISSR belirteçleri kullanarak yaptıkları çalışmadan elde edilen AMOVA sonuçlarına göre, 2 gruba ayrılan aksesyonlara bakıldığında, İran gruplarında ve egzotik gruplarda çeşitliliğin büyük oranda aksesyonlar içinde (sırasıyla \%80.21 ve \%80.42) olduğu bildirilmiştir. Rasouli ve ark. (2013) tarafindan yapılan çalışmada populasyonlar arası çeşitliliğgin düşük (\%22) ve populasyonlar içi çeşitliliğin yüksek $(\% 78)$ olduğu bildirilmiş ve populasyon içi varyasyonun yüksek olmasının yüksek gen akışı ile ilgili olduğu düşünülmektedir.

Çalışmamızda populasyonlar arası genetik farklılaşma düzeyi, Nei'nin tarafsız genetik benzerlik ve farklılık katsayıları kullanılarak hesaplanmıştır (Nei, 1987). Genetik farklılık değerlerine baktığımızda Özerbey ve Lütfübey populasyonları arasında en düşük (0.018), Pleven ve Kırşehir-1 populasyonları arasında da en yüksek (0.058) bulunmuştur. Bu sonuçlara göre, Pleven ve Kırşehir-1 populasyonları genetik yapılarına göre birbirine en uzak populasyonlardır. Ülkemizde tescilli ilk iki çeşidi olan Özerbey ve Lütfübey birbirlerine en yakın çeşitler olarak belirlenmiştir. Burada aynı bölgeden olan Kırşehir-1 ve Kırşehir-2 populasyonlarının birbirinden uzak olmaları, Kırşehir ilinin farklı bölgelerinden toplanan populasyonlar olduğunu düşündürmektedir. Avcı ve ark. (2014)'nın 58 korunga taksonunda yaptıkları çalışmada, Nei'nin genetik benzerlik değeri 0.013 ile 0.399 arasında hesaplanmıştır. Onobrychis genomlarına benzerlik gösteren P. vulgaris ve M. trancatula genomları arasındaki \%10'luk farkın korunga çalışmalarında yakın akrabalarından kullanılacak primerlerin sınırlı olduğunu göstermiştir. Nosrati ve ark. (2012) farklı bölgelerden 5 yabani korunga populasyonunda genetik mesafe değerini 0.635 ile 0.165 arasında bildirmiştir. Burada coğrafi mesafelerden çok ekolojik etkinin genetik varyasyona etki ettiği ve genetik varyasyonun çevresel koşullarla ilişkisinin ya doğal seleksiyon yada lokal gen ayrımı nedeniyle olduğu düşünülmüştür. Çalışmamızda kullandığımız SSR primerleri Kempf ve ark. (2016) tarafından korungaya spesifik geliştirilen ilk primerlerdir. Korungaya özgü geliştirilen primerleri kullanarak yaptığımız bu çalışma türün genetik çeşitliliği, populasyon arası ve populasyonlar içi varyasyonu belirleyerek bundan sonra yapılacak olan çalışmalara kaynak sağlayacaktır. Ayrıca türün genetik yapısını ortaya çıkararak sahip olduğumuz biyoçeşitlilikten faydalanmada yol gösterecektir. Korunga gibi üzerinde çalışılması gereken yem bitkilerinin özellikle marjinal alanlarda yetişebilen bu tür bitkilerin genomlarında gizli kalmış bilgiler açığa çıkartılarak, sslah çalışmalarıyla yeni 
çeşitler geliştirilecek ve tarıma kazandırılacaktır.

\section{Teşekkür}

Korunga populasyonlarına ait tohumların temini ve çalışmaya olan katkılarından dolayı Prof. Dr. Metin TUNA'ya (Namık Kemal Üniversitesi, Ziraat Fakültesi, Tarla Bitkileri Bölümü, Çayır Mera Yem Bitkileri Anabilim Dalı) teşekkür ederiz. Bu çalışma TÜBİTAK (Proje No: 21505261) tarafından kısmi olarak desteklenmiştir. 


\section{Kaynakça/References}

Açıkgöz, E. (2001). Yem Bitkileri. Uludağ Üniversitesi, Ziraat Fakültesi, Tarla Bitkileri Bölümü, 83-94 s., Bursa.

Aktoklu, M. (1995). Türkiye'de yetişen Onobrychis Miller (Fabaceae) türlerinin revizyonu. Doktora Tezi, İnönü Üniversitesi Fen Bilimleri Ens., Biyoloji Anabilim Dalı, $134 \mathrm{~s}$

Avc1, S., İlhan, E., Erayman, M., Sancak, C. (2014). Analysis of Onobrychis genetic diversity using SSR markers from related legume species. The Journal of Animal \& Plant Sciences. 24(2): 556-566.

Bhattarai, S. (2017). Characterization of diverse germplasm of sainfoin (Onobrychis viciifolia Scop.) using agro-morphological traits and aftp molecular markers. (Thesis Degree of Master of Science). Department of Plant Science, University of Saskatchewan, Saskatoon, Canada.

Botstein, D., White, R.L., Skolnick, K., Davis, R.W. (1980). Construction of a genetic linkage map in man using restriction fragment length polymorphism. American Journal of Human Genetics. 32: 314-331.

Carbonero, C.H. (2011). Sainfoin (Onobrychis viciifolia), a forage legume with great potential for sustainable agriculture, an insight on its morphological, agronomical, cytological and genetic characterisation. (Doctor of Philosophy Thesis). Faculty of Life Sciences, Manchaster, United Kindom.

Demdoum, S., Munoz, F., Delgado, I., Valderrabano, J., Wunsch, A. (2012). EST-SSR cross amplification and genetic similarity in Onobrychis genus. Genetic Resources and Crop Evolution. 59: 253-260.

Doyle, J.J., Doyle, J.I. (1990). Isolation of plant DNA from fresh tissue. Focus. 12: 13-15.

Elçi, Ş. (2005). Baklagil ve buğdaygil yem bitkileri, T.C. Tarım ve Köyişleri Bakanlığı, s. 223-257, Ankara.

Healey, A., Furtado, A., Cooper, T., Henry, R.J. (2014). Protocol: a simple method for extracting next-generation sequencing quality genomic DNA from recalcitrant plant species. Plant Methods. 10: 21

Hejrankesh, N., Haghighi, A.R., Mousavizadeh, S.A. Rashidi, V. (2014). Evaluation of genetic diversity of sainfoin (Onobrychis viciifolia Scop.) landraces using RAPD markers. Journal of Current Research in Science. 2: 739-748.

Kempf, K., Mora-Ortiz, M., Smith, M.J., Kölliker, R., Skot, L. (2016). Characterization of novel SSR markers in diverse sainfoin (Onobrychis viciifolia) germplasm. BMC Genetics. 17: 124.

Nei, M. (1987). Molecular evalutionary genetics. Columbia University Press, New York. 512 p.

Nosrati, H., Feizi, M.A.H., Tarrah, S.S., Haghighi, A.R. (2012). Population genetic variation in sainfoin (Fabaceae) revealed by RAPD markers. Analele Universităţii din Oradea - Fascicula Biologie. 1: 11-16.

Nosrati, H., Feizi, M.A.H., Latifian, F., Haghighi, A.R. (2016). Eco-Geographical variations of ISSRs among populations of Onobrychis viciifolia (Sainfoin, Fabacae). Analele Universităţii din Oradea, Fascicula Biologie. 2: 62-66.

Özalp, T., Temel, O. (2016). Artvin'in Şavşat ilçesinde yetiştirilen korunga (Onobrychis viciifolia Scop.) yem bitkisinin kalitesi ve verimi üzerine yükseltinin ve bazı toprak özelliklerinin etkisi. Anadolu Tartm Bilimleri Dergisi. 31: 106-116.

Özbek, H. (2011). Korunga (Onobrychis viciifolia SCOP.): Önemli bir arı bitkisi. Uludă̆ Arıcılık Dergisi. 11(2): 51-62.

Özkan, U., Demirbağ, S. (2016). Türkiye'de kaliteli kaba yem kaynaklarını mevcut durumu. Türk Bilimsel Derlemeler Dergisi. 9(1): 23-27.

Peakall, R., Smouse, P.E. (2006). GENALEX 6: Genetic analysis in excel. population genetic software for teaching and research. Molecular Ecology Notes. 6: 288-295.

Rasouli, M., Jaferi, A.A., Tabaei-Aghdaei, S.R., Shanjani, P.S., Darvish, F. (2013). Assesment of genetic variability of 36 populations of sainfoin (Onobrychis sativa) based on RAPD markers. International Journal of Biosciences. 3(10): 15-26.

Roldan-Ruiz, I., Dendauw, J., Van Bockstaele, E., Depicker, A., De Loose, M. (2000). AFLP markers reveal high polymorphic rates in rygrasses (Lolium spp.). Molecular Breeding. 6: 125-134.

Schuelke, M. (2000). An economic method for the fluorescent labeling of PCR fragments. Nature Biotechnology. 18: 233-234.

Sneath, P.H.A., Sokal, R.R. (1973). Numerical taxonomy: the principles and practice of numerical classification. W.H. Freeman and Co., San Francisco. $573 \mathrm{pp}$

Souza, H.A.V., Muller, L.A.C., Brandao, R.L., Lovato, M.B. (2012). Isolation of high quality and polysaccharide-free DNA from leaves of Dimorphandra mollis (leguminosae), A Tree From The Brazilian Cerrado. Genetics and Molecular Research. 11(1): 756-764.

Tamura, K., Stecher, G., Peterson, D., Filipski, A., Kumar, S. (2013). MEGA6: molecular evolutionary genetics analysis version 6.0. Molecular Biology and Evolution. 30(12): 2725-2729.

Tosun, F. (1992). Bitki Yetiştiriciliğinin Fizyolojik Esasları. OMÜ Ziraat Fakültesi Tarla Bitkileri Bölümü Ders Notları No:5, 244 s, Samsun.

Zarrabian, M., Majidi, M.M. (2015). Genetic diversity and relationships within and among Onobrychis species using molecular markers. Turkish Journal of Botany. 39: 681-692.

Zarrabian, M., Majidi, M.M., Ehtemam, M.H. (2013). Genetic diversity in a worldwide collection of sainfoin using morphological,anatomical, and molecular markers. Crop Science. 53: 2483-2496. 